\title{
Factors affecting entrepreneurship of educational management students in Andimeshk Payame Noor University
}

\author{
Sakineh Ghayazi ${ }^{1, *}$, Faranak Omidian ${ }^{2}$, Mohammed Hosseinpoor ${ }^{1}$ \\ ${ }^{1}$ Department of Educational Management, Khuzestan Science and Research Branch, \\ Islamic Azad University, Khuzestan, Iran \\ ${ }^{2}$ Department of Education, Dezfoul Branch, Islamic Azad University, Dezfoul, Iran \\ *E-mail address: sghayazi@yahoo.com
}

\begin{abstract}
The goal of this study was to search for the factors affecting entrepreneurship of educational management students in Andimeshk Payame Noor University in 2012-2013. That was a survey and the research method was descriptive. The statistic population included 400 full time members of faculties in these universities and 200 participants were selected based on accidental sampling. The tool used in this survey was a questionnaire which included 33 statements. The validity of questionnaire was emphasized and accepted by 10 experts in this field and the reliability of questionnaire was determined based on Chronbach's Alpha coefficient and the number was 0.93 . For the analysis of data, a combination of descriptive and inferential techniques including independent $\mathrm{T}$ test and Friedman ranking test was used. Findings indicated by $95 \%$ of assurance the individual, social and economical factors affect on the educational management students' entrepreneurship in order according to the students views.
\end{abstract}

Keywords: educational management; entrepreneurship; Payame Noor students

\section{INTRODUCTION}

In recent years the entrepreneurship category has been paid attention in our country, thus this concept is unfamiliar for many experts and people in the society. For this reason, a suitable planning in social, economical and educational domains of Iran for developing entrepreneurship have not been applied especially in the universities. In recent conditions that Iran economy is faced with the problems like unemployment (especially in educated persons with university degrees), shortage of experienced human resources, decreasing the government funds, inaction and outgrowth of economy, educating and training excellent entrepreneurship persons is more important than before (Ahmadpoordariani and Moghimi, 2006). Nowadays, a far larger number of higher education graduated students made governmental and individual systems overfull and also the organizations are so less for them to fit jobs. This causes these persons to prefer migrate to other countries and made unemployment of graduated students a threat for our country (Larigani and Shabaninegad, 2010). 
This is the time when competition $\mathrm{n}$ in economy is depended on the innovation and technological abilities of the young. This needs applying the best management models in systems and developing young skills in human resources. One of the strategies for this is applying entrepreneurship by universities themselves.

The university strategy toward technology should be leading entrepreneurship to create employment chances for the young. For this reason, university masters are not able to have such a task themselves. It needs different governors, planners and masters help to create necessary physical situations in which the economical jobs are planned and the graduated students can be employed. The structure experienced in most countries is the growth center of business and technology. The factors of entrepreneurship more than universities affect expansion of students' entrepreneurship (Shafizadeh and Pardakhtchi, 2006). So in this research, we studied the factors affecting educational management students' entrepreneurship and based on the research problem, the following research questions summarized and the aim is to answer these questions:

Q1. What are the social factors affecting the entrepreneurship of educational management students from students' views?

Q2. What are the economical factors affecting the entrepreneurship of educational management students from students' views?

Q3. What are the individual factors affecting the entrepreneurship of educational management students from students' views?

Q4. What are the priorities of factors affecting the entrepreneurship of educational management students?

\section{PREVIOUS RESEARCHES}

There are different approaches about entrepreneurship definition and the concept of this word needs information of interdicipliny approaches. Entrepreneurship, according to its identity and different views of experts such as psychologists, is defined as sociology, economy, industry and even history (Azizi, 2003). Entrepreneurship process is called "Creativity destruction". In other words the characteristic of entrepreneurship is doing new works and innovating modern ways in daily life. The modern way is just "Creativity destruction". To his view, entrepreneur is a person who has new and modern idea and by a process of starting and creating a business and accepting the risk, introduces new productions and services to the society. Entrepreneurship is never done without certain pre-needs of business management (recognizing opportunities, preparing resources and creating business activities), so its teaching cannot be done without emphasizing on these pre-needs (Ahmadpoordariani and Moghimi, 2006).

Imani (2009) in a research titled "the teaching of entrepreneurship in the universities; a frame for planning, applying and evaluating" got the results that in the entrepreneurship, plans and programs for preparing graduated students of this field in the universities, four elements of psychology and its goals, literature review, entrepreneurship programs elements and environmental activities should be paid attention and needs of the groups under study are different. At last based on the research result a framework for planning, applying and evaluating of entrepreneurship plans in teaching entrepreneurship was suggested. Hosseini et al (2009) in a research titled "the factors affecting the entrepreneurship of Tehran agriculture colleges' students" studied six varieties of teaching extra program skills related to jobs skills, creative teaching method in the university, suitable contents for courses in university, having 
ability and active skill in the field of the course instructors taught. The results showed that these named items are more important factors in the university. The results of Turker (2008) showed the supporting factors in the university affect the students' motivation for entrepreneurship. If the university develops such programs, the interest and motivation of students will increase.

The other result showed that social supporting factors affect the students' entrepreneurship. In other words, the supports of all levels in the society toward entrepreneurship process self-belief of students and finally provide a better attitude of students' entrepreneurship. Of course it should be said supporting factors affect more than social factors on the students [7]. Ruda et al (2009) in a research by applying searching analyzing factors in discovery affecting factors of entrepreneurship gives a conceptual framework of interpreting self-employment of students. He knew self-employment an upper pace more than entrepreneurship. Entrepreneurship has mental aspects and defined as the process of recognizing, making photographs and growing individual goals and visions in a competitive environment, as self-employment refers to the groups or persons creating new jobs in an economic dimension or to establish trade organizations and offices. These researches believe if self-employment characteristics are recognized in the students, planning entrepreneurship programs will be easy. It needs a range of levels. In the lowest level of selfemployment are the unemployment students.

They are motivated by low needs. This motivation has high risk ability according to getting advantages but free of any routine knowledge. In high level, there is an understanding about self-employment. These students are rarely motivated by low needs and they are motivated by self- blossom needs. In higher level, there is a willing toward self-employment. These students are not motivated by low needs for self-employment. They are ready to have necessary tests for self-employment.

Finally the students who can provide an office or organization for work are called a self-employment student ( Ruda et al, 2009). Tanveer et al (2013) in their study titled "studying the entrepreneurship obstacles for management students in Pakistan" told that the most important barriers were the lack of necessary skills, the lack of financial and humanity support, the lack of knowledge and information about creating jobs and entrepreneurship and a fear about future. As this report said most management students had not knowledge, skill and enough experience for entrepreneurship.

The most important items were the weakness in educational system from elementary to university in teaching entrepreneurship skills and creating a positive attitude toward entrepreneurship. So teaching entrepreneurship is one of the most important tasks of universities and educational systems. Also this research pointed to government support and personal support for using suitable strategies to solve this problem.

\section{RESEARCH METHOD}

This study was a survey and the research method was descriptive. The statistic population included 400 students of educational management and 200 participants were selected based on random sampling. The tool used in this survey was a questionnaire which included 33 statements. The validity of questionnaire was emphasized and accepted by 10 experts in this field and the reliability of questionnaire was determined based on Chronbach's Alpha coefficient and the number was 0.93 . For the analysis of data, a combination of 
descriptive and inferential techniques including independent $\mathrm{T}$ test and Friedman ranking test was used.

\section{FINDINGS AND DATA ANALYSIS}

In this section of paper we present statistical analysis results of the research hypotheses.

Question 1. What are the social factors affecting the entrepreneurship of educational management students from students' views?

Nineteen statements have been included in questionnaire to study the social factors affecting the entrepreneurship of educational management students in Payame Noor University of Andimeshk. The detailed data on 19 statements are as followed:

Table 1. The main descriptive data and Friedman ranking in social domain of entrepreneurship.

\begin{tabular}{|c|c|c|c|}
\hline Statements & Mean & SD & $\begin{array}{c}\text { Friedman } \\
\text { Ranking }\end{array}$ \\
\hline $\begin{array}{l}\text { 1. Entrepreneurship affects on the motivation and } \\
\text { attract of faculties to pass entrepreneurship } \\
\text { training courses }\end{array}$ & 4.47 & 0.59 & 1 \\
\hline $\begin{array}{c}\text { 2. Teaching entrepreneurshipin the universities } \\
\text { affect culture of entrepreneurship and reflection } \\
\text { of it }\end{array}$ & 4.32 & 0.67 & 3 \\
\hline $\begin{array}{l}\text { 3. Teaching entrepreneurship affect discovering } \\
\text { new opportunities. }\end{array}$ & 4.35 & 0.79 & 2 \\
\hline $\begin{array}{l}\text { 4. Teaching entrepreneurship are much paid } \\
\text { attention in higher education }\end{array}$ & 3.81 & 1.1 & 18 \\
\hline $\begin{array}{l}\text { 5. Being familiar with the process of } \\
\text { entrepreneurship through university training } \\
\text { affects future possibilities of students jobs }\end{array}$ & 4.23 & 0.75 & 7 \\
\hline $\begin{array}{l}\text { 6. Applying strategic planning in education affect } \\
\text { students' entrepreneurship }\end{array}$ & 4.17 & 0.82 & 9 \\
\hline $\begin{array}{l}\text { 7. Having visions and missions in educational and } \\
\text { noneducational organizations affect students' } \\
\text { entrepreneurship }\end{array}$ & 4.11 & 0.78 & 14 \\
\hline $\begin{array}{l}\text { 8. Predicting future and having views in } \\
\text { educational organizations affect students' } \\
\text { entrepreneurship }\end{array}$ & 4.11 & 0.80 & 13 \\
\hline $\begin{array}{l}\text { 9. The amount of using models of developed } \\
\text { countries in the field of employing young people } \\
\text { affect students' entrepreneurship }\end{array}$ & 3.98 & 0.99 & 16 \\
\hline $\begin{array}{c}\text { 10. organizations' planning to employ young } \\
\text { based on their experience affect students' } \\
\text { entrepreneurship }\end{array}$ & 4.12 & 0.97 & 11 \\
\hline
\end{tabular}




\begin{tabular}{|c|c|c|c|}
\hline $\begin{array}{c}\text { 11. educational organizations notices to attract } \\
\text { young men affect students' entrepreneurship }\end{array}$ & 4.15 & 0.92 & 10 \\
\hline $\begin{array}{c}\text { 12. University know the entrepreneurship } \\
\text { concepts and affect the reflection of } \\
\text { entrepreneurship }\end{array}$ & 3.98 & 0.95 & 17 \\
\hline $\begin{array}{c}\text { 13. University has made the students familiar with } \\
\text { entrepreneurship by showing films and CDs about } \\
\text { students' entrepreneurship }\end{array}$ & 3.58 & 1.2 & 19 \\
\hline $\begin{array}{c}\text { 14. presence of consulters and guiders in } \\
\text { university to make students familiar with } \\
\text { entrepreneurship affect students' entrepreneurship }\end{array}$ & 4.11 & 0.95 & 12 \\
\hline $\begin{array}{c}\text { 15. Society supporting in reinforcing and } \\
\text { motivating creativity and innovation affect } \\
\text { students' entrepreneurship }\end{array}$ & 4.05 & 0.94 & 15 \\
\hline $\begin{array}{c}\text { 16. The lack of structure and ... of industry in } \\
\text { country affect students' entrepreneurship }\end{array}$ & 4.21 & 0.97 & 4 \\
\hline $\begin{array}{c}\text { 17. The laws and disciplines of educational } \\
\text { organizations affect students' entrepreneurship }\end{array}$ & 4.24 & 0.79 & 6 \\
\hline $\begin{array}{c}\text { 18. Government planning in ... affect students' } \\
\text { entrepreneurship }\end{array}$ & 4.24 & 0.88 & 5 \\
\hline $\begin{array}{c}\text { 19. Accepting responsibility of managers in } \\
\text { organizations affect students' entrepreneurship }\end{array}$ & 4.18 & 0.87 & 8 \\
\hline
\end{tabular}

Given the above table, the first statement (Entrepreneurship affects on the motivation and attract of faculties to pass entrepreneurship training courses) with 4.47 has the most mean and the thirteen statement (University has made the students familiar with entrepreneurship by showing films and CDs about students' entrepreneurship) has the least mean among the nineteen statements in social domain from the factors affecting the entrepreneurship of educational management students of Payame Noor University. Also according to Friedman ranking the first statement is the most effective statement and statement thirteen is the least effective statement in social domain.

Question 2. What are the economical factors affecting the entrepreneurship of educational management students from students' views?

Six statements have been included in questionnaire to study the economical factors affecting the entrepreneurship of educational management students in Payame Noor University of Andimeshk.

The detailed data on 6 statements are as followed: 
Table 2. The main descriptive data and Friedman ranking in economical domain of entrepreneurship.

\begin{tabular}{|c|c|c|c|}
\hline Statements & Mean & SD & $\begin{array}{c}\text { Friedman } \\
\text { Ranking }\end{array}$ \\
\hline $\begin{array}{c}\text { 20. University trial to propagate } \\
\text { entrepreneurship and grow small industries } \\
\text { affects students entrepreneurship }\end{array}$ & 4.14 & 0.77 & 1 \\
\hline $\begin{array}{c}\text { 21. Teaching entrepreneurship increase the } \\
\text { students willing to start cooperative business } \\
\text { (in small and average companies) }\end{array}$ & 4.11 & 0.80 & 2 \\
\hline $\begin{array}{c}\text { 22. Reinforcement of individual part in the } \\
\text { economy of country affects students } \\
\text { entrepreneurship }\end{array}$ & 3.93 & 0.91 & 6 \\
\hline $\begin{array}{c}\text { 23. Knowledge of knowing selling } \\
\text { environment affects on creating attitude of } \\
\text { students toward entrepreneurship }\end{array}$ & 4.07 & 0.94 & 3 \\
\hline $\begin{array}{c}\text { 24. Existence of investors (financial, timing } \\
\text { and expertise ones) in society affects students } \\
\text { entrepreneurship }\end{array}$ & 4.10 & 0.89 & 0.83 \\
\hline $\begin{array}{c}\text { 25. Creating balance between investors } \\
\text { values and society needs affects students } \\
\text { entrepreneurship }\end{array}$ & 4.03 & 5 \\
\hline
\end{tabular}

Given the above table, the 20 statement (University trial to propagate entrepreneurship and grow small industries affects students entrepreneurship) with 4.14 has the most mean and the 22 statement (Reinforcement of individual part in the economy of country affects students entrepreneurship) with 3.93 has the least mean among the six statements in economical domain from the factors affecting the entrepreneurship of educational management students of Payame Noor University. Also according to Friedman ranking the 20 statement is the most effective statement and statement 22 is the least effective statement in economical domain.

Question 3. What are the individual factors affecting the entrepreneurship of educational management students from students' views?

Eight statements have been included in questionnaire to study the individual factors affecting the entrepreneurship of educational management students in Payame Noor University of Andimeshk. The detailed data on 8 statements are as followed:

Table 3. The main descriptive data and Friedman ranking in individual domain of entrepreneurship.

\begin{tabular}{|c|c|c|c|}
\hline Statements & Mean & SD & $\begin{array}{c}\text { Friedman } \\
\text { Ranking }\end{array}$ \\
\hline $\begin{array}{c}\text { 26. Having divergent thinking affects students } \\
\text { entrepreneurship }\end{array}$ & 4.11 & 0.83 & 4 \\
\hline $\begin{array}{c}\text { 27. Self-motivation of students affects their } \\
\text { entrepreneurship }\end{array}$ & 4.10 & 0.99 & 5 \\
\hline
\end{tabular}




\begin{tabular}{|c|c|c|c|}
\hline $\begin{array}{c}\text { 28. The students' hard-working ability is one of } \\
\text { the basic factors in making entrepreneurship } \\
\text { successful }\end{array}$ & 4.16 & 0.93 & 2 \\
\hline $\begin{array}{c}\text { 29. Having independence mentality affects } \\
\text { creating willing toward entrepreneurship }\end{array}$ & 4.23 & 0.88 & 1 \\
\hline $\begin{array}{c}\text { 30. There is a relationship between the person's } \\
\text { study and entrepreneurship ability }\end{array}$ & 4.07 & 0.93 & 6 \\
\hline $\begin{array}{c}\text { 31. Having critical thinking affects students } \\
\text { entrepreneurship }\end{array}$ & 4.10 & 0.95 & 5 \\
\hline $\begin{array}{c}\text { 32. Having willing to expose in danger affects } \\
\text { creating willing toward entrepreneurship }\end{array}$ & 4.12 & 0.92 & 3 \\
\hline $\begin{array}{c}\text { 33. Teaching entrepreneurship affects willing } \\
\text { to expose in danger in the students }\end{array}$ & 4.04 & 0.93 & 7 \\
\hline
\end{tabular}

Given the above table, the 29 statement (Having independence mentality affects creating willing toward entrepreneurship) with 4.11 has the most mean and the 33 statement (Teaching entrepreneurship affects willing to expose in danger in the students) with 4.04 has the least mean among the eight statements in individual domain from the factors affecting the entrepreneurship of educational management students of Payame Noor University. Also according to Friedman ranking the 29 statement is the most effective statement and statement 33 is the least effective statement in individual domain.

Question 4. What are the priorities of factors affecting the entrepreneurship of educational management students?

Table 4. Friedman ranking test for factors affecting students' entrepreneurship in Andimeshk Payame Noor University.

\begin{tabular}{|c|c|c|}
\hline Statements & Mean & Ranking \\
\hline 1. Social dimension & 2.63 & 2 \\
\hline 2. Economical dimension & 2.36 & 3 \\
\hline 3. Individual dimension & 2.69 & 1 \\
\hline
\end{tabular}

Given the above table, according to Friedman ranking individual dimension with the amount of 2.69 showed a great effect on entrepreneurship of management students and economical dimension with the amount of 2.36 showed a little effect on entrepreneurship of management students in Andimeshk Payame Noor University.

Question 5. Is there any difference between male and female students' views in factors of the entrepreneurship (social, economical, individual)? 
Table 6. Independent $T$ test to signify the numbers' difference of factors affecting entrepreneurship of management students according to the male and female students' views.

\begin{tabular}{|c|c|c|c|c|c|c|c|c|c|c|}
\hline \multirow{2}{*}{ Dimension } & \multirow{2}{*}{$\begin{array}{l}\text { students } \\
\text { Gender }\end{array}$} & \multicolumn{2}{|c|}{ Lewen test } & \multirow{2}{*}{$\mathbf{N}$} & \multirow{2}{*}{ Mean } & \multirow{2}{*}{ SD } & \multirow{2}{*}{$\begin{array}{c}\text { Mean } \\
\text { Difference }\end{array}$} & \multirow{2}{*}{ D.F } & \multirow{2}{*}{$\begin{array}{c}\mathbf{T} \\
\text { value }\end{array}$} & \multirow{2}{*}{ Sig. } \\
\hline & & $\mathbf{F}$ & Sig. & & & & & & & \\
\hline \multirow{2}{*}{ Social } & Women & \multirow{2}{*}{2.65} & \multirow{2}{*}{0.10} & 115 & 4.11 & 0.46 & \multirow{2}{*}{0.32} & \multirow{2}{*}{198} & \multirow{2}{*}{0.956} & \multirow{2}{*}{0.64} \\
\hline & Men & & & 85 & 4.14 & 0.51 & & & & \\
\hline \multirow{2}{*}{ Economical } & Women & \multirow{2}{*}{0.138} & \multirow{2}{*}{0.71} & 115 & 4.04 & 0.62 & \multirow{2}{*}{0.39} & \multirow{2}{*}{198} & \multirow{2}{*}{0.314} & \multirow{2}{*}{0.65} \\
\hline & Men & & & 85 & 4.08 & 0.57 & & & & \\
\hline \multirow{2}{*}{ Individual } & Women & \multirow{2}{*}{0.019} & \multirow{2}{*}{0.88} & 115 & 4.13 & 0.59 & \multirow{2}{*}{0.38} & \multirow{2}{*}{198} & \multirow{2}{*}{2.50} & \multirow{2}{*}{0.65} \\
\hline & Men & & & 85 & 4.09 & 0.58 & & & & \\
\hline
\end{tabular}

As shown in table 6, the results of lewen test showed that the amount of $T$ for the difference of means from factors affecting entrepreneurship in management students of Andimeshk Payame Noor University is not significant at the significant level of 0.05 from male and female students' views. It means that this hypothesis is not rejected male and female management students of Andimeshk Payame Noor University have the same opinion about the effect of social, economical and individual factors of entrepreneurship.

\section{SUMMARY AND CONCLUDING REMARKS}

The achieved results of first hypothesis showed that there is a significant relationship between social factors and the entrepreneurship of management students of Andimeshk Payame Noor University. This result is compatible with the results of Gholipoor (2008) research told that there is a significant relationship between social fund and its dimensions and entrepreneurship and there is a direct relationship between them, also increasing entrepreneurship. For emphasizing and reasoning this result it can be said that there is a relationship between social place and the mentality of entrepreneurship. Entrepreneurship is a process placed at a social environment and these relationships can facilitate the entrepreneurship relationship with resources easier or limited. In today society of Iran, entrepreneurs' barriers regardless of political and economical items and regarding socialcultural barriers like not paying attention to social relationships. In fact a social entrepreneur is regarded as a tool of conception for social varieties. If one wants to have an important and main effect on environment around one's, and designs the other parts so as to be supported by others, he/she should have the ability to motivate others well and make the communications with others as well as possible. So, while this concept makes an opportunity for social changes, it should be paid attention in any part of the society. Also it could be said social fund have a great role for entrepreneurship and it can't be as a creator of it. But for creating creativity in an entrepreneur and lead it to entrepreneurship, different social factors has their 
important role and one of them is social fund. An entrepreneur for succeeding needs to have academic experience to try them and change its concept. In fact changes in attitudes and social behavior are affected by social entrepreneur characteristic and provided resources such as family knowledge and support.

The achieved results of second hypothesis showed that there is a significant relationship between economical factors and the entrepreneurship of management students of Andimeshk Payame Noor University. This result is compatible with the results of Ghaderi (2005) research told that there is a significant difference between managers' entrepreneurship skills and organizations' effectiveness, also there is a positive relationship between managers' entrepreneurship skills and organizations' effectiveness in small business (getting advantages, growth, getting resources).

For emphasizing and reasoning this result it can be said that entrepreneur is one of the main factors of economical values and useful tool for creating employment and decreasing employment, also entrepreneurship increases economical growth and improve life standards. So, as we know, the society is changing all the time and entrepreneur should not only help economical growth, but also create modern innovations which are the main factors of facing needs. So in entrepreneurship process, an entrepreneur recognizes new opportunities and creates new business which often has some risks [Ghaderi, and Esmaeel, 2005; Moghimi and Moghimi, 2008 ).

The achieved results of third hypothesis showed that there is a significant relationship between individual factors and the entrepreneurship of management students of Andimeshk Payame Noor University.

This result is compatible with the results of Azizi (2003) research told that there is a positive relationship among the varieties of belief to internal control, progress motivation and independence with entrepreneurship. Also the results have complete compatibility with the results of the research of Badri (2005), Hosseini (2009), Hezargaribi (2009) there is a significant relationship between entrepreneurship and individual skills and also between entrepreneurship and progress motivation and with Derisen (1997) told that the most important factor in entrepreneurship of person is entrepreneurship characteristic. For emphasizing and reasoning this result it can be noted that individual factors and common characteristics include accepting risks, willing to get results from job, independence financial, knowledge, positive view, and bearing to reach the goals.

When entrepreneur has good attitude during work; he/she has no doubt while facing the problems and this sense causes the creativity to be increased and work is done with selfconfidence, with devoting time to it and with trial to accept financial, mental and social risks to get financial resources, personal satisfaction and individual independence.

This causes the entrepreneurship to introduce new products and services to the society, and also recognizes opportunities and find strategies to use these opportunities. 


\section{References}

[1] Ahmadpoordariani Mahmood, Moghimi Mohammad, (2006). The basic concepts of entrepreneurship, Farandisheh Pub., (in Persian).

[2] Azizi Mohammad, (2003). Studying the context of showing and training entrepreneurship in B.A and M.A students of Shahid Beheshti University, M.A thesis, Shahid Beheshti University, Tehran, (in Persian).

[3] Badri Ehsan, Liaghatdar Mohammadgavad, (2005). Studying the entrepreneurship o Isfahan University.

[4] Driessen M. P., Zwart P. S., (1997). The Role of the Entrepreneur inn Small Business Success: The Entrepreneurship Scan.

[5] Ghaderi Esmaeel, (2005). The relationship between entrepreneurship skills of managers and organizational effectiveness in low and average business (SMEs) of Ghom State, M.A thesis of Ghom Pardis.

[6] Gholipoor Rahmatalah, Madhushi Mehrdad, Gafarian Vahid. The analysis of relation and effect of social fund on organizational entrepreneurship: a case study of Sadid industrialized group, Organizational Culture Management Journal 17 (2008) (in Persian).

[7] Hezargaribi Gafar, Bolandian Gholamhossein, (2006). A study on conceptualization of safety harm, quarterly in study of defence, Supper International Defence University, $7^{\text {th }}$ year, Vol. 27.

[8] Hosseini Seyed Mahmood (2009). Effective factors on entrepreneurship of agiculture colleges' students of Tehran, Science and Propagation of Teaching Agriculture in Iran, Vol. 5, No. 2., (in Persian).

[9] Imani Mohammadnaghi, (2009). Teaching entrepreneurship in universities: a framework for planning, applying and evaluating entrepreneurship programs, Quarterly of Research Educational Management, (in Persian).

[10] Larigani Narges, Shabaninegad Esmaeel, (2010). Studying entrepreneurship in university and higher education institutes of Payame Noor, Tonkabon Center.

[11] Moghimi Abolfazl, Moghimi Hossein, (2008). Studying the relationship of social fund on organizational entrepreneurship in Plastic industrial company, Yazd, the First National Conference of Developing Economical Activities.

[12] Ruda W., Martin T. A., Danko B., (2009), Target Group-Specific Design of Student Entrepreneurship Support - A German Example Focusing on Start-Up Motives and Barriers. Acta Polytechnic Hungarian 6(3) (2009).

[13] Shafizadeh Hamid, Pardakhtchi Mohammad Hassan, (2006). A study on organization entrepreneurshipArasbaran pub. Tehran, (in Persian).

[14] Tanveer M. A., Gillani U. A. U., Rizvi S., Latif M., Maqbool Rizwan H. M., Journal of Basic and Applied Scientific Research 3(1) (2013) 718-72.

[15] Turker D., Sonmez Selcuk, Journal of European Industrial Training 33(2) (2008) 142-155. 
[16] Mohamad Khaledian, Zahra Ahmadimehr, Elham Naseri, Fakhralsadat Khosravani, Mojgan Shoshtsri, International Letters of Social and Humanistic Sciences 8 (2013) 43-48.

[17] Monirosadat Hosseini, Mohamad Jafre Zainol Abidin, Hamid Kamarzarrin, Mohamad Khaledian, International Letters of Social and Humanistic Sciences 11 (2013) 66-75.

[18] Hamid Maleki, International Letters of Social and Humanistic Sciences 7 (2014) 62-66.

[19] Morteza Ziaee, International Letters of Social and Humanistic Sciences 9 (2014) 57-65.

[20] Mohamad Khaledian, Majid Omidi, Mandana Sepanta, Mehdi Tavana, International Letters of Social and Humanistic Sciences 9 (2014) 108-114. 